\title{
Fin erosion of perch Perca fluviatilis and ruffe Gymnocephalus cernua in a pulp mill effluent area
}

\author{
Eric Lindesjöö ${ }^{1}$, Jan Thulin ${ }^{2}$ \\ ${ }^{1}$ Department of Zoology, Uppsala University, Box 561, S-751 22 Uppsala, Sweden \\ ${ }^{2}$ The National Swedish Environmental Protection Board, Marine Section, Box 584, S-740 71 Öregrund, Sweden
}

\begin{abstract}
Very high frequencies, up to $80 \%$, of fin erosion of perch Perca fluviatilis and ruffe Gymnocephalus cernua have been found in the area of a pulp mill releasing bleached kraft mill effluents, situated at the Swedish coast of the Gulf of Bothnia. In the effluent area, which was studied between 1984 and 1988, a gradient was established of both acute and healed fin erosion, showing decreasing frequencies with increasing distance from the pulp mill outlet. No fish from a reference area were found with these fin damages. Acute fin erosion was not found after 1984 which was congruent with a distinct decrease in discharge from the pulp mill. However, healed stages of fin erosion, i.e. regenerated fin rays resulting in a very specific scar on the fins, were still present with highest frequencies closest to the mill. The study clearly indicates that fin erosion of perch and ruffe in the effluent area was caused by the bleached kraft mill effluents from the pulp mill.
\end{abstract}

\section{INTRODUCTION}

Pollution has often been discussed as being a major trigger for the development of certain fish diseases, e.g. skeletal deformities, fin erosion, ulcerations and tumours. Several field studies have indicated the presence of these relations but factors such as a nonstationary behaviour of fish and lack of a pronounced, specific, pollution gradient have made such correlations hard to prove (Mix 1986, Thulin 1986, Malins et al. 1988, O'Connor \& Huggett 1988).

In a multidisciplinary project, the effects on the aquatic ecosystem of effluents from a Swedish pulp mill using chlorine for bleaching have been studied during several consecutive years (reviewed by Södergren 1989). The biological effect studies were mainly concentrated on a stationary fish, the perch Perca fluviatilis and compared the effects from the cell to the population level. One of the studies concerned diseases of fish in which a pronounced disease sign, i.e. fin erosion, was found in very high frequencies in the effluent area.

Fin rot/fin erosion is a common pathological condition of the fins of bony fishes. The primary stage of the disease is a slight necrosis of the skin beginning with the distal part of the fin. If the disease process stops at this stage the fin will regenerate either partially or completely. However, if the disease continues to develop the necrosis progresses down to the base of the fin leaving it as a short stump. In this severe case the fin cannot regenerate. The etiological agents of fin rot have been attributed to several species of flexibacteria (Post 1983). However, during the last $15 \mathrm{yr}$, fin rot/fin erosion has often been associated with environmental pollution by various authors, and in the majority of cases bacteria have not been found. This type of fin damage, in which there is no demonstrable infectious agent, is preferably called fin erosion. The most detailed studies of fin erosion have been made on winter flounder Pseudopleuronectes americanus in New York Bight (Murchelano 1975, Ziskowski \& Murchelano 1975) and on dover sole Microstomus pacificus in California Bight (Mearns \& Sherwood 1974, McDermott-Ehrlich et al. 1977, Sherwood \& Mearns 1977, Cross 1984). Sindermann (1984) proposed 'actions of chemical stressors on mucus and/or epithelium' as being one possible cause of this disease condition.

This paper describes the occurrence of fin erosion of perch Perca fluviatilis and ruffe Gymnocephalus cernua in a bleached kraft mill effluent area located in an archipelago at the Gulf of Bothnia, Baltic Sea, Sweden. Preliminary results of the study were presented by Lindesjöö \& Thulin (1987) and Thulin et al. (1988, 1989). The histopathology of perch will be published elsewhere. 


\section{MATERIALS AND METHODS}

Investigation areas. Fish were sampled from 3 areas during 1984 to 1988 (Fig. 1): Norrsundet (pulp mill with bleaching), Sandarne (pulp mill without bleaching) and Forsmark (reference). All 3 areas are situated in shallow areas at the SW coast of the Bothnian Sea, Northern Baltic. The salinity in the areas is stable $(4 \%)$ and

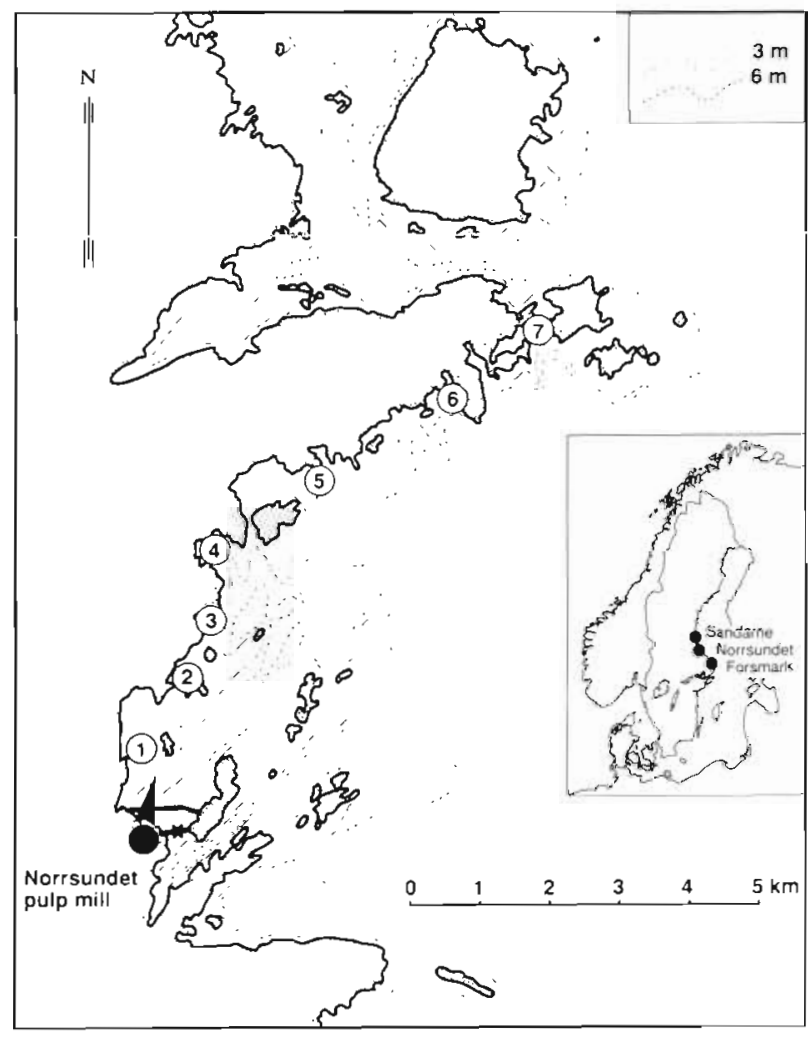

Fig. 1. Map of Norrsundet pulp mill effluent area showing the discharge point at Norrsundet (arrow) and the investigation stations ( 1 to 7 ). Insert shows location of pulp mills (Norrsundet, Sandarne) and reference area (Forsmark) there are no major freshwater inputs or other local pollution sources. The topography of the discharge areas at the pulp mills allowed gradient studies, i.e. sampling stations of similar depths and exposure to the open sea, similar temperature, climate, and sampling stations were available at appropriate distances from the effluent discharge point, etc.

Bleached sulphate pulp is produced at the Norrsundet mill. The yearly production between 1979 and 1988, and effluent characteristics are presented in Table 1. Bleaching starts with an oxygen delignification. The pulp is distributed to 2 bleaching lines with the sequences $\mathrm{O}(\mathrm{C} 85+\mathrm{D} 15)(\mathrm{EO}) \mathrm{D}$ and $\mathrm{O}(\mathrm{C} 85+\mathrm{D} 15)$ (EO)DED (where $\mathrm{C}=$ chlorine, $\mathrm{D}=$ chlorine dioxide, $\mathrm{E}$ $=$ sodium hydroxide $\mathrm{O}=$ oxygen) (C85+D15) implies in this case that about $15 \%$ chlorine dioxide has been added to the chlorine stage; $(\mathrm{E}+\mathrm{O})$ implies that the alkali stage is boosted with oxygen. The kappa number of the pulp after the oxygen stage is about 18 to 20 . The carry-over of released matter from the oxygen stage in the bleaching plants corresponds to about $10 \mathrm{~kg}$ COD (chemical oxygen demand) per tonne of pulp. The effluent characteristics were fairly representative for Swedish, bleached sulphate pulp mills in the beginning of the 1980's. Although pulp production increased, reconstructions in 1982/1983 and further technical improvements of the process technique led to the total discharges of COD and organochlorine compounds decreasing considerably, which resulted in a markedly lower environmental load in 1985 to 1988. The mill effluents were diluted approximately 60 times at the discharge point as they were mixed with sea-water pumped from a nearby bay. The calculated dilution of the effiuent from the Norrsundet mill is shown in Fig. 2. This figure also shows a gradient of contamination exemplified by the content of $\mathrm{EOCl}$ (extractable organic chlorine) in the muscle of perch (Södergren 1989, modified)

Table 1 Effluent characteristics and production (in 1000 t) data from Norrsundet pulp mill between 1979 and 1988 . Susp: suspended solids (kg $\left.24 \mathrm{~h}^{-1}\right)$; $\mathrm{COD}$ : chemical oxygen demand $\left(\mathrm{t} 24 \mathrm{~h}^{-1}\right)$; $\mathrm{Cl}$ : elementary chlorine used in bleaching (t $\mathrm{yr}^{-1}$ ); - : missing data. Total phosphorus $(\mathrm{P})$ and nitrogen $(\mathrm{N})$ given in $\mathrm{kg} 24 \mathrm{~h}^{-1}$. Data supplied by Norrsundet Bruk $\mathrm{AB}$

\begin{tabular}{|c|c|c|c|c|c|c|c|}
\hline Year & $\begin{array}{c}\text { Total } \\
\text { production }\end{array}$ & $\begin{array}{l}\text { Bleached } \\
\text { production }\end{array}$ & Susp. & COD & $\mathrm{Cl}$ & Total P & Total N \\
\hline 1979 & 156 & 119 & 5600 & 65 & 10070 & 40 & 150 \\
\hline 1980 & 145 & 112 & 3670 & 52 & 10154 & 20 & 180 \\
\hline 1981 & 145 & 125 & 3660 & 63 & 11063 & 60 & 250 \\
\hline 1982 & 133 & 121 & 2240 & 53 & 10649 & 30 & 150 \\
\hline 1983 & 203 & 203 & 2230 & 69 & 11931 & - & - \\
\hline 1984 & 234 & 234 & 1780 & 51 & 8731 & 37 & 80 \\
\hline 1985 & 222 & 222 & 1800 & 36 & 6774 & 26 & 105 \\
\hline 1986 & 228 & 228 & 2000 & 40 & 6911 & 28 & 104 \\
\hline 1987 & 240 & 240 & 1000 & 36 & 6894 & 37 & - \\
\hline 1988 & 244 & 244 & 1300 & 37 & 6215 & 36 & 110 \\
\hline
\end{tabular}




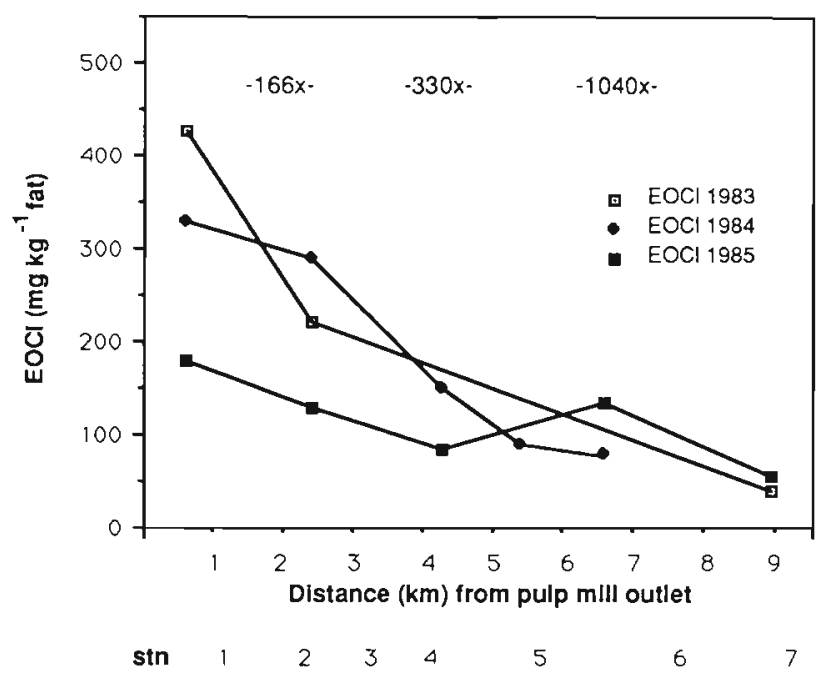

Fig. 2. Perca fluviatilis. EOCI (extractable organic chlorine) in muscle of perch from Norrsundet effluent area and calculated dilution (166 $\times$ etc.) of effluent. Data modified from Södergren (1989)

Sandarne pulp mill, which is situated in a coastal area similar to that at Norrsundet (Fig. 1), has a pulp process similar to that at Norrsundet except that it produces unbleached pulp and discharges only about $1 / 4$ the amount of COD. The Forsmark area is unaffected by pulp mill activities and was used as a reference area.

Field sampling. A field study was performed during 1984 to 1988 . With the exception of the first sampling at Norrsundet in May 1984 all fish were caught by gill net (survey net). These nets were composed of 5 parts with $17,21,25,33$ and $60 \mathrm{~mm}$ mesh bars, respectively. During the first sampling at Norrsundet fish were caught by gill net of only one size - with $25 \mathrm{~mm}$ mesh bars. Total length of the fish was measured, the operculum of perch was sampled for age determination, and fins were fixed for histological examination. At Norrsundet altogether 1960 perch were examined from 7 stations (localities) in a gradient from the discharge point (Fig. 1). At Sandarne, 95 perch from the area closest to the discharge point were examined during 1985. From the reference area at Forsmark, a total of 1550 perch were examined. Ruffe were examined only in 1985: 501 from the stations at Norrsundet, 95 at Sandarne, and 87 at Forsmark.

Diagnostic method. In 1984 at Norrsundet, and at the other 2 localities during all sampling periods, fish were examined fresh, directly in the field. In 1985 at Norrsundet all fins (except the first dorsal fin) of perch and ruffe were cut individually from each specimen and mounted on a sheet of paper. To prevent bias, each sheet was individually coded and mixed between stations and sampling periods before examination. During

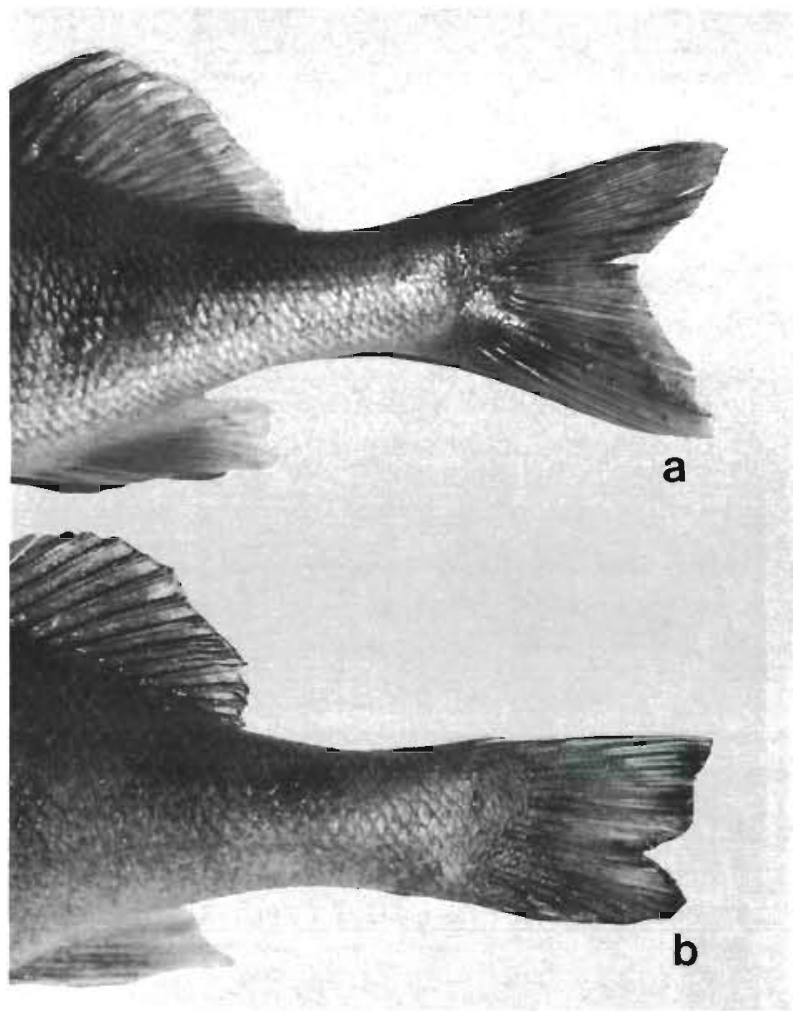

Fig. 3. Perca fluviatilis. Perch with (a) normal fins and (b) fins affected by acute fin erosion (Category 1 )

samplings at Norrsundet in 1986 and 1988 only the left pelvic fin was cut off and examined. Fins were graded into the following 5 Categories: 1 = acute fin erosion (total loss of distal part of fins) (Fig. 3b); $2=$ severe deformations/curvatures of the fin rays distal to an area of fracture (Fig. 4a); 3 = curvatures of the fin rays distal to an area of fracture (Fig. 4 b) ; $4=$ oscillations of the fin rays without any area of fracture (Fig. 4c); $5=$ normal fin without any notable oscillations of the fin rays (Fig. $4 \mathrm{~d}$ ). Category 4 is a fin anomaly which is known to occur in frequencies around $20 \%$ in all perch populations along the coast line in question.

Fin regeneration experiment. To study the regenerating capacity of the fins, $1 / 3$ of the upper part of the caudal fin of 25 perch $(14$ to $23 \mathrm{~cm})$ from Forsmark was cut off. These tests were made at Forsmark during all seasons with 5 to 10 specimens being kept in a cage between 1 and 6 mo before examination. The cage was an opaque plastic barrel with a volume of 901 , and with 120 holes $(8 \mathrm{~mm})$ at each flank and bottom. The top of the cage was without holes to prevent exposure to direct sunlight. Cages were moored horizontally halfway between the surface and the bottom.

Statistical analyses. Anomaly frequencies were analyzed for statistically significant differences 


\section{RESULTS}
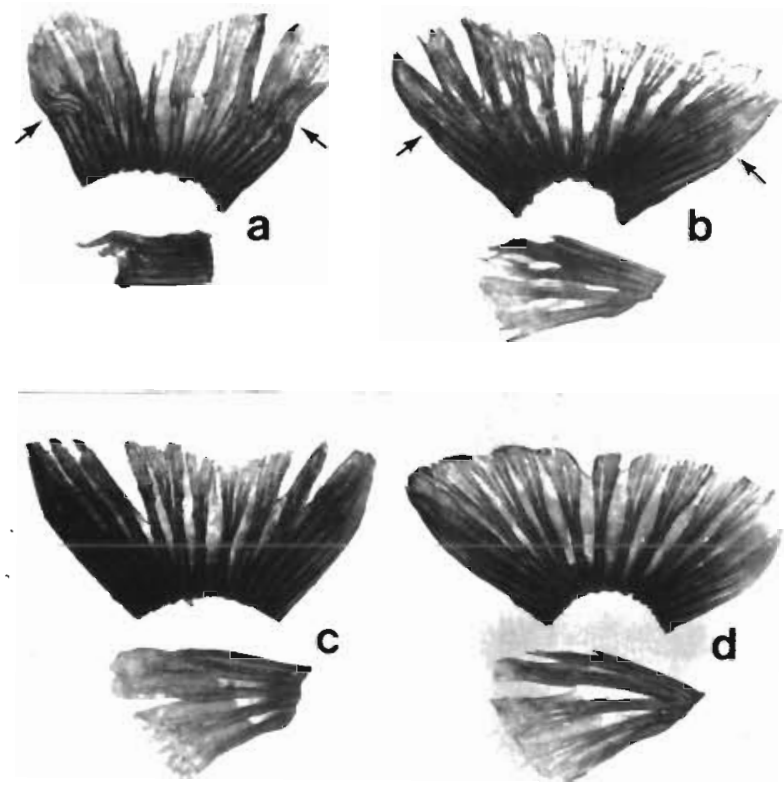

Fig. 4. Perca fluviatilis. Fin erosion Categories 2 to 5 (a to d, respectively) of the caudal and pelvic fin of perch. Arrows indicate area of fracture

between fin Category 2 and 3 for the different stations by a binomial test. Furthermore, of the material from 1985 the frequencies of Categories 2 and 3 were pooled and analyzed for significant differences between the different stations in the Norrsundet area by a Chisquare test. The significance level 0.05 was chosen for both tests.

\section{Perch}

During 1984, perch from the Norrsundet area exhibited 2 types of fin damage: a necrosis of the distal part (Fig. 3b), i.e. acute fin erosion (Category 1), and a distinct deformation/curvature of the distal parts of the fin rays (Figs. 4 and 5), (Categories 2 and 3). The fin cutting experiment, which resulted in a regeneration of fins, left the regenerated part with curvatures of the fin rays similar to those found at Norrsundet. This indicated that the second type of damage found at Norrsundet was the result of a healed fin erosion. All fins of perch (excent the first dorsal fin) with healed erosion had similar deformations. However, the pelvic fin was found to have the most recognizable deformation, which made us choose to sample only this fin during 1986 and 1988.

Acute fin erosion was found only on one occasion (May 1984) and only at Stn 2, i.e. the station closest to the Norrsundet mill (Fig. 6). On this occasion, $66 \%$ of perch had eroded fins and $17 \%$ were found with healed fins. Of the 31 specimens found with eroded fins, 29 had erosion of all fins except the first dorsal fin which was never found affected. At Stn 4, during the same year, perch with healed fin erosion were found during all 3 sampling periods while no fin damage at all was found on perch at Stn 6. During the following year, 1985, no perch were found with acute fin erosion, but high frequencies of healed erosion were still evident (Fig. 7). The frequencies of healed fin erosion during June was $50 \%$ at Stn 1 and decreased to $6 \%$ at Stn 5 , while no perch were found with erosion at Stns 6 and 7 .

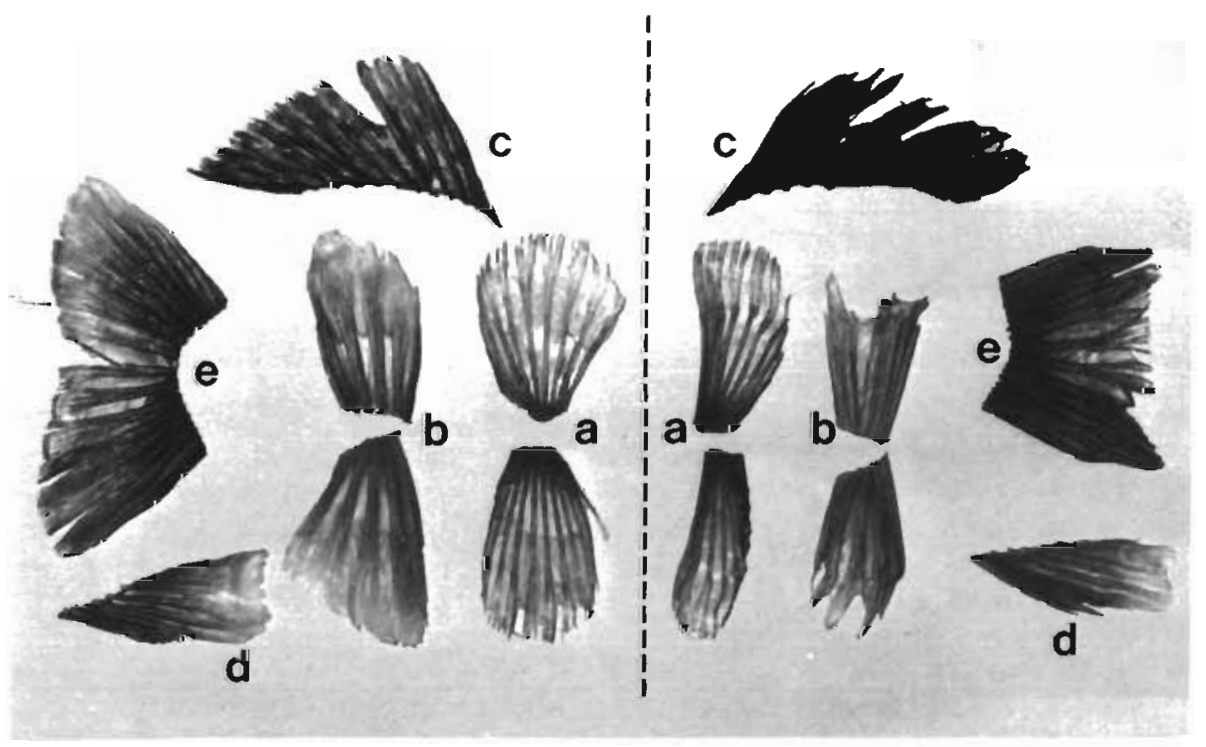

Fig. 5. Perca fluviatılis. Normal perch fins to the left and those with deformations/curvatures of the fin rays as a result of healed fin erosion to the right: (a) pectoral fins, (b) pelvic fins, (c) second dorsal fin, (d) anal fin, (e) caudal. fin 


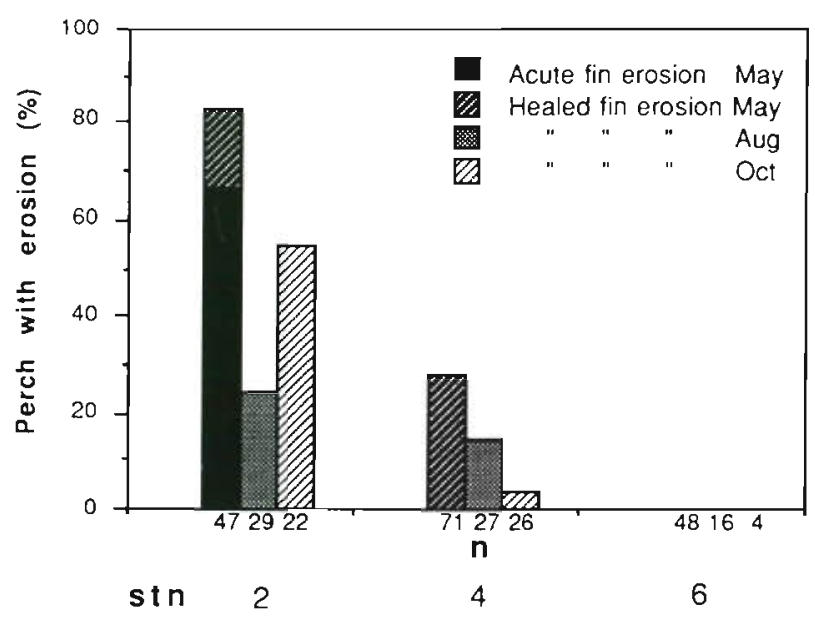

Fig. 6. Perca fluviatilis. Frequency of fin erosion of perch at different distances from the Norrsundet pulp mill in $1984 ;(n)$ no. fishes

During August, of the same year, the same pattern as in June was found but with frequencies reduced by half at Stns 1 to 4 . Healed fins were also found at Stn 6 at a very low frequency $(4 \%)$. Since no significant difference was found between frequencies of damage Categories 2 and 3 these 2 groups were combined when the data were analyzed statistically between the stations. Category 4 was found with a similar distribution in the whole sequence of stations and no correlation was found with the polluted area. The Chi-square test of Categories 2 and 3 showed significant differences between stations during both June and August (Table 2). In June there was a 'demarcation' between Stns 1 to 4 and 5 to 7 . The pattern was similar in August but the 'demarcation' moved towards Stn 6 . The sampling in September 1986 showed a high frequency of healed fin erosion at $\operatorname{Stn} 3(21 \%)$. However, low frequencies ( 2 to $7 \%$ ) were found at the other stations (Fig. 7). The last sampling in July 1988 showed
Table 2. Perca fluviatilis. Paired Chi-square test on the frequencies of fin erosion Categories 2 and 3 of perch sampled from different localities in Norrsundet pulp mill effluent area.

(+) significantly different at $p<0.05$; ( $)$ not significant

\begin{tabular}{|ccccccc|}
\hline \multicolumn{7}{c}{ Station } \\
Stn & 7 & 6 & 5 & 4 & 3 & 2 \\
\hline June 1985 & & & & & & \\
1 & + & + & + & - & - & - \\
2 & + & + & + & - & - & \\
3 & + & + & + & - & & \\
4 & + & + & + & & & \\
5 & - & - & & & & \\
6 & - & & & & & \\
August 1985 & & & & & & \\
1 & + & + & - & - & - & \\
2 & + & + & - & - & - & \\
3 & + & + & - & - & - & \\
4 & + & - & - & & & \\
5 & + & - & & & \\
6 & - & & & & \\
\hline
\end{tabular}

decreasing frequencies in the whole area. In this sampling, as in all others, the majority of fin-damaged fish was found at stations closest to the pulp mill.

None of the examined perch from the reference area or from Sandarne pulp mill was found with any of the fin damages described above.

With the exeption of the first sampling at Norrsundet, the distribution of length and year classes of perch in the different investigation areas were the same with a fish length/age ranging between $13-35 \mathrm{~cm}$ and $2-11 \mathrm{yr}$ and with a mean length/age of $21 \mathrm{~cm}$ and $4 \mathrm{yr}$. Because of a larger size of gill net used at the first sampling at Norrsundet the length distribution was different at this occasion with a length/age ranging between $22-35 \mathrm{~cm}$ per 4-12 yr and with a mean leng th/age of $27 \mathrm{~cm}$ and $7 \mathrm{yr}$. Due to the lack of young specimens in this catch it was not possible to look for a direct relationship between length/
Fig. 7. Perca fluviatilis. Frequency of healed fin erosion of perch at different distances from the Norrsundet pulp mill between 1985 and 1988; (n) no. fishes

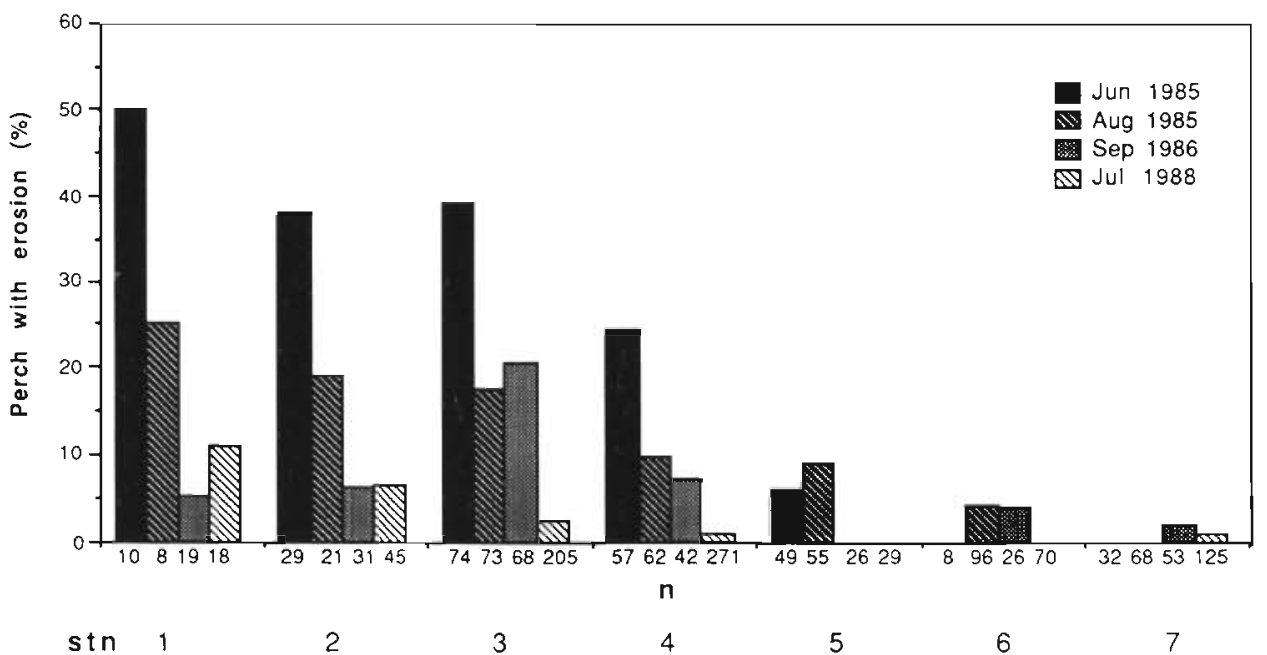




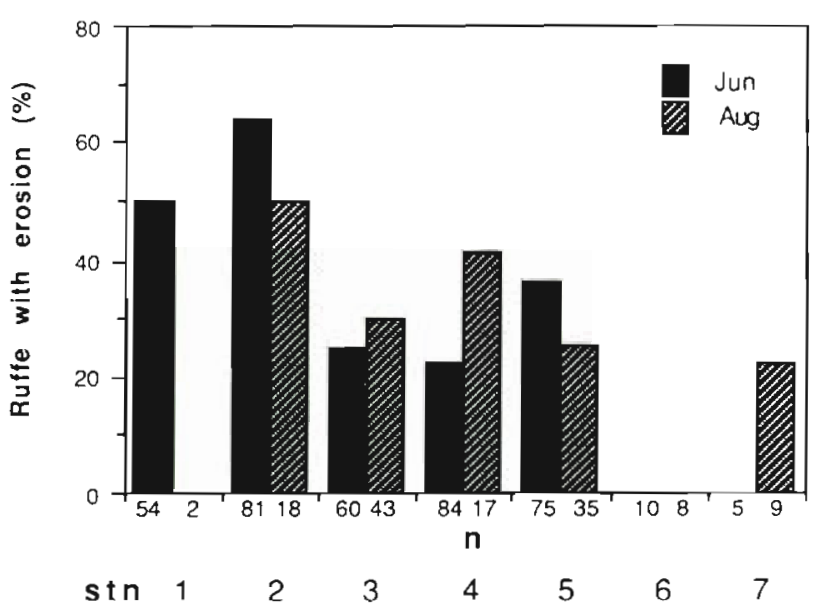

Fig. 8. Gymnocephalus cernua. Frequency of fin erosion of ruffe at different distances from the Norrsundet pulp mill in 1985; (n) no. fishes

age and acute fin erosion. During 1985 the majority of perch with healed fin erosion ranged between $17-24 \mathrm{~cm}$ and 3-6 yr. They were equally distributed compared with fish with unaffected fins and no relationship between length/age/sex and healed fin erosion was found. During the last sampling in 1988 all perch affected by healed fin erosion were 5 yr or older which indicates that no erosion has been induced after 1984 .

\section{Ruffe}

During 1985 ruffe were found with the same type of healed fin erosion as found earlier in the perch. The frequencies were very high with a maximum of $64 \%$ recorded at Stn 2 in June (Fig. 8). The damage was, however, more pronounced than on perch and several specimens exhibited incomplete healing of fins. Three specimens were found with one of their fins without any regeneration at all. Because of the small number of ruffe caught at Stns 6 and 7 during both sampling periods, it was not possible to make any comparison between the inner and outer stations. In contrast to perch, a significantly increased frequency of severe fin damage (Category 2 vs Category 3) was found on ruffe at Stn 1 in June 1985 (Fig. 9).

Like perch, none of the examined ruffe from the reference station or from Sandarne pulp mill was found with any fin damage.

\section{DISCUSSION}

The present study has shown a clear correlation between a specified pollution source, bleached kraft mill effluents, and a specific fish disease sign, fin ero-

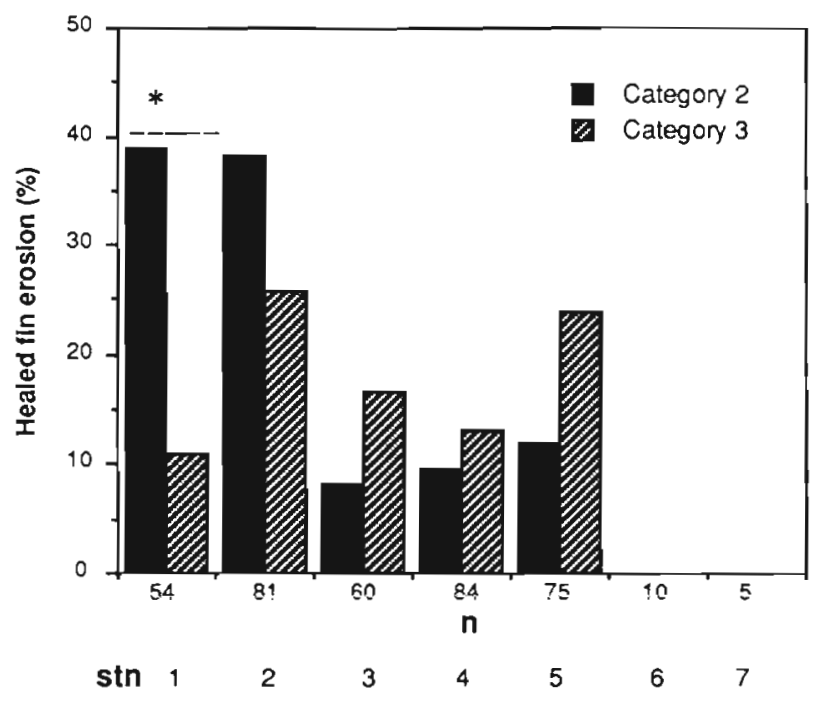

Fig. 9. Gymnocephalus cernua. Frequencies of fin erosion Categories 2 and 3 of ruffe at different distances from the Norrsundet pulp mill in June 1985; (n) no. fishes; asterisk: significant difference between fin erosion Categories 2 and 3 at $\mathrm{p}<0.05$

sion. It has further been shown that a fin affected by fin erosion may regenerate, thereby marking the fin for several years. Fin damage of both perch and ruffe was found only in the vicinity of Norrsundet pulp mill, with decreasing frequencies at increasing distance from the discharge point.

Acute fin erosion of perch was found only on one occasion, i.e. closest to the pulp mill in May 1984. However, acute fin erosion and 'bleeding fins' of perch and ruffe as well as of other fish species like pike Esox lucius, roach Rutilus rutilis, and rudd Scardinius erythrophthalmus, were noticed regularly during both 1982 and 1983 at stations closest to the pulp mill (Sandström pers. comm.). These observations indicate that the total frequency of fin damaged perch, especially at the station closest to the mill, had its maximum in May 1984 and then decreased during the following sampling periods. The absence of acute fin erosion after May 1984 can very likely be linked to the considerably improved water quality due to the decreased discharges from the pulp mill, particularly after 1984. The character of the bottoms in the receiving bodies of water, being erosion and/or transport bottoms instead of accumulation bottoms (Södergren 1989), combined with the temporary closing down of the pulp mill du ring the summer of 1985 , have probably contributed to the quick recovery of the effluent area. During 1985 and 1986 there was a comparatively faster reduction in the frequencies of perch with healed fin erosion at stations close to the pulp mill. This could be due to the increased rate of mortality recorded among fin damaged perch in this area (Sandström \& Thoresson 1988). 
It is interesting to note that all fins except the dorsal one in perch were found to be affected by fin erosion This might be explained by the more aberrant construction of this fin which is made up of homogeneous, hard, fin rays while all other fins are composed of paired hemisegments without any supporting skeleton (Lanzing 1976).

The majority of perch caught with healed fin erosion during 1985 were between 3 and 6 yr, i.e. 2 to 5 yr during 1984, which could indicate that the erosion had been induced only in the first years. However, this seems unlikely since perch with acute fin erosion caught in May 1984 were 5 to 10 yr old. Therefore, it seems probable that acute fin erosion was not related to any specific age/length. This is also supported by our results of healed fin erosion where no relationship between length/age/sex and fin damage was found. Similar findings has been found by Möller (1984) who showed that no relationship seems to exist between specific length/age groups and prevalence of fin rot.

The observations clearly indicate that the fin erosion was induced in the inner part of the area (Stns 1 to 4 ). This is congruent with the results obtained in studies of the water flows and flow paths in the Norrsundet area, which shows the lowest water flows and consequently low dilution of the process water in the inner area (Kolset \& Heiberg 1988). Furthermore, a gradient of decreased levels of $\mathrm{EOCl}$ was found in sediment traps as well as in muscle tissue of perch with increasing distance from the pulp mill (Södergren 1989).

General fish ecology studies in the Norrsundet area showed a decreased density of the fish community closest to the outlet which was interpretated as the result of the eutrophicating, toxic and repelling properties in the area (Neumann \& Karås 1988). The finding of the highest impact on the fish in the most polluted area was also in parity with the findings made in a fish physiology study in the same area in which visibly affected as well as unaffected perch were examined. Here it was shown that toxic effects were most pronounced in fish from the inner area. However, some disturbances could be observed in the whole effluent area (Andersson et al. 1988). The effects included enlarged liver, very strong induction of certain cytochrome P-450-dependent enzyme activities in the liver, elevated levels of ascorbic acid in liver tissue, abnormal carbohydrate metabolism, marked effects on white blood cell pattern and alterations in the red blood cell status and in the ion balance, results which indicate that the immune defence system of the fish was impaired. Furthermore, it has also been shown that perch with healed fin erosion caught in October 1984 and August 1985 had gonads that were significantly less developed than those of unaffected perch (Sandström et àl. 1988)
The results described above from a brackish water area of the Baltic Sea were further supported by a comparative study recently made in the southern hemisphere in a river in New Zealand (Lindesjöö \& Thulin 1988, mimeographed). The river Kopakorahi Stream is used as a recipient by a pulp mill which discharges effluents similar to those discharged by the Norrsundet mill. In a gradient, with the highest frequencies closest to the outlet, we found goldfish Carassius auratus, with frequencies up to $36 \%$ of acute and healed fin erosion of the same macroscopical appearance as the fish with fin erosion from Norrsundet. Furthermore, in histological sections the affected fins of the goldfish did not show any presence of bacterial aggregates (Lindesjöö unpubl. data).

The significantly higher frequency of severe fin damage found on ruffe at $\operatorname{Stn} 1$, the station closest to the mill, might be explained by the different biology of this fish compared with that of perch. Ruffe, like perch, is a stationary but more benthic fish which probably leads to an increased exposure to toxic substances from the bottom sediments. Studies made on dover sole off Los Angeles, showed that fish living on highly polluted sediments develop fin erosion which is more severe on fins that come in contact with the sediments (Sherwood \& Mearns 1977). The fin damage on ruffe in the Norrsundet area was generally more pronounced than that on perch, and ruffe with acute fin erosion were still found during a test fishing programme in the discharge area in late August 1984 (Sandstrom pers. comm.) in spite of the improved water quality. All these findings may indicate that ruffe have a different susceptibility to fin erosion than perch and that this may be reflected in the different distribution of fin erosion of ruffe in the area compared with perch.

The results of the experimental cutting of fins clearly indicated that the curvature of the fin rays was caused by the healing process. It further showed that the regeneration speed was temperature dependent and only occurred at temperatures above $10^{\circ} \mathrm{C}$. This is in accordance with the general temperature dependence of growth for perch (Karås 1987).

In conclusion, a clear correlation between the occurrence of fin erosion of perch and ruffe and bleached, kraft mill effluents has been found outside Norrsundet pulp mill, Sweden. Furthermore, we have clear indications that the disease can be found in other countries and areas where these effluents occur. It was also shown that no outbreaks of the disease occurred after changes and improvements in the industrial process at Norrsundet resulting in a markedly lower environmental load. This leads to a conclusion that fin erosion of perch and ruffe living in the vicinity of Norrsundet was caused by effluents from the pulp mill 
Acknowledgements: This study was financed by the Research Council at the National Swedish Environmental Protection Board (SNV) and the Hierta Retzius foundation. We thank I. Abrahamsson and R.-M. Svensson at SNV for technical assistance, J. Höglund, at Department of Zoology, Uppsala, for comments on the sampling technique, A. McVicar at DAFS, Aberdeen, P. Karås and O. Sandström, SNV, for comments on the manuscript, G. Thoresson at SNV for the statistical treatment, and K. Wilund, Soderhamn, for assistance with the field work.

\section{LITERATURE CITED}

Andersson, T., Förlin, L., Härdig, J., Larsson, A. (1988). Physiological disturbances in fish exposed to bleached kraft mill effluents. Can. J. Fish. Aquat. Sci. 45: 1525-1536

Cross, J. N. (1984). Fin erosion among fishes collected near a southern California municipal wastewater outfall (1971-1982). Fish. Bull. U.S. 83: 195-206

Karås, P. (1987). Food consumption, growth and recruitment in perch Perca fluviatilis $L$. PhD thesis at Uppsala University, Uppsala

Kolset, K., Heiberg, A. (1988). Evaluation of the fugacity (FEQUM) and the EXAMS fate and transport models. Case studies on the pollution of the Norrsundet Bay. Sweden. Wat. Sci. Tech. 20: 1-12

Lanzing, W. J. R. (1976). The fine structure of fins and fin rays of Tilapia mossambica. Cell Tissue Res. 173: 349-356

Lindesjöö, E., Thulin, J. (1987). Fin erosion of perch Perca fluviatilis in a pulp mill effluent. Bull. Eur. Ass. Fish Pathol. 7: $11-13$

Lindesjöö, E., Thulin, J. (1988). Diseases of fish living in the Kinleith pulp and paper mill effluent area. A report from a short time study, 16-25 November 1988. Report to NZFP, New Zealand. Mimeographed

Malins, D. C., McCain, B. B., Landahl, J. T., Myers, M. S., Krahn, M. M., Brown, D. W., Chan, S.-L., Roubal, W. T (1988). Neoplastic and other diseases in fish in relation to toxic chemicals: an overview. Aquat. Toxic. 11: 43-67

Mix, M. M. (1986). Cancerous diseases in aquatic animals and their association with environmental pollutants: a critical literature review. Mar environ. Res. 20: 1-141

McDermott-Ehrlich, D. J., Sherwood, M. J., Heesen, T. C.,

Responsible Subject Editor: Dr G. Peters, Hamburg,

F. R. Germany
Young, D. R. and Mearns, A. J. (1977). Chlorinated hydrocarbons in dover sole, Microstomus pacificus: local migrations and fin erosion. Fish. Bull. U.S. 75: 513-517

Mearns, A. J., Sherwood, M. J. (1974). Environmental aspects of fin erosion and tumors in southern California dover sole. Trans. Am. Fish. Soc. 103: 799-810

Murchelano, R. A. (1975). The histopathology of fin rot disease in winter flounder from the New York Bight. J. Wildl. Dis 11: $263-267$

Neuman, E., Karås, P. (1988). Effects of pulp mill effluent on a Baltic coastal fish community. Wat. Sci. Tech. 20: 95-106

Möller, H. (1984). Dynamics of fish diseases in the lower Elbe River. Helgoländer Meeresunters. 38: 389-413

O'Connor, J. M., Huggett, J. (1988). Aquatic pollution problems, North Atlantic coast, including Chesapeake Bay. Aquat. Toxic. 11: 163-190

Post, G. W. (1983). Textbook of fish health. TFH Publications, Inc. Ltd., Neptune City

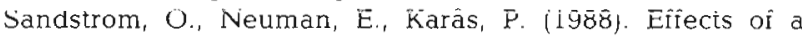
bleached pulp mill effluent on growth and gonad function in Baltic coastal fish. Wat. Sci. Tech. 20: 107-118

Sandström, O., Thoresson, G. (1988). Mortality in perch populations in a Baltic pulp mill effluent area. Mar. Pollut. Bull. 19: $564-567$

Sherwood, M. J., Mearns, A. J. (1977). Environmental significance of fin erosion in southern California demersal fishes Ann. N.Y. Acad. Sci. 298: 177-189

Sindermann, C. J. (1984). Fish and environmental impacts Arch. FischWiss. Berlin 35: 125-160

Södergren, A. (ed.) (1989). Biological effects of bleached pulp mill effluents. Final report from the Environment/Cellulose I Project. National Swedish Environmental Protection Board, Solna Report 3558

Thulin, J. (Ed.) (1986). Report of the ICES workshop on the use of pathology in studies of the effects of contaminants ICES, C.M. 1986/E.40, Ref.: F

Thulin, J., Höglund, J., Lindesjöö, E. (1988). Diseases and parasites of fish in a bleached kraft mill effluent. Wat. Sci. Tech. 2: 179-180

Thulin, J., Höglund, E., Lindesjöö, E. (1989). Fisksjukdomar kustvatten. Fish diseases in coastal waters of Sweden. (In Swedish with an English summary). Naturvårdsverket Förlag, Solna ISBN 91-620-1063-8

Ziskowski, J., Murchelano, R. (1975). Fin erosion in Winter flounder. Mar. Pollut. Bull. 6: 267-269

Manuscript first received: December 21, 1989

Revised version accepted: April 2, 1990 